\title{
03. Eski Türkçenin söz varlığında tanıklanan ıçgın- ve örgin sözcüklerinde geçen \{-gI-\} eki
} Ahmet KARAMAN'

APA: Karaman, A. (2021). Eski Türkçenin söz varlığında tanıklanan ıçgın- ve örgin sözcüklerinde geçen \{-gI-\} eki. RumeliDE Dil ve Edebiyat Araştırmaları Dergisi, (Ö9), 35-42. DOI: 10.29000/rumelide.981496.

\section{Öz}

Eski Türkçenin söz varlığı içerisinde hem yazıt ve el yazmaları hem Eski Uygur hem de Karahanlı Türkçesi metinlerinde geçen ıçgın- ve örgin sözcüklerinin etimolojik çözümlemeleri konusunda belirsizlikler bulunmaktadır. Içgın- sözcüğünün sonundaki \{-n-\} ve örgin sözcüğünün sonundaki \{-n\} eki tespit edilebilir durumdadır. Bu tespitten başka bu iki sözcüğün kök biçimleri ile kök biçimleri \{-n-\} / \{n\} ekine bağlayan fiiller ve her iki sözcüğün de aldığı anlaşılan ikinci ek konusunda Türkolojide bir boşluk vardır. Her iki sözcügün de yapısında görülen bu ikinci ek, \{-gI-\} eki gibi görünmektedir. \{-gI-\} eki, ıçgınve örgin sözcüklerinin etimolojik açıdan açıklanması noktasında önemli bir yere sahiptir. Eski Türkçenin söz varlığı ve söz yapımı üzerine hazırlanan etimoloji sözlüklerinde yer almayan bu ekin varlığı, ıçgın-ve örgin sözcükleri derinlemesine incelendiğinde kaçınılmaz görünmektedir. Çünkü özellikle örgin sözcüğünün açıklanmasında tanık gösterilen ve Şine Usu yazıtının güney onuncu satırında geçen örgifiili, bu durumun anlaşılmasında kilit bir role sahiptir. Yapılan bu çalışmada ilk olarak Eski Türkçenin söz varlığından örnek tanıklamalarla ıçgın- ve örgin sözcüklerinin karşıladıkları anlamlar üzerinde durulacaktır. Sonrasında, ilgili sözcükler için sunulmuş etimoloji önerilerine eleştirel bir bakış açısıyla değinilecektir. Daha sonrasında, bu iki sözcüğe kaynaklık etmiş olduğu düşünülen kök biçimler ve sözcüklerin aldığı ekler açıklanmaya çalışılacaktır. Yazının son bölümünde ise çıkan sonuçlar ışığında Clauson, Gabain, Erdal, Orkun ve Tekin gibi araştırmacıların tespitlerinde bulunmayan \{-gI-\} ekinin yapısal ve anlamsal görünümü üzerinde durulacaktır.

Anahtar kelimeler: ıçgın-, örgin, \{-gI-\} eki, etimoloji, Eski Türkçe

\section{The $\{$-gI- $\}$ suffix in the ıçıın- and örgin words witnessed in the Old Turkic vocabulary}

\begin{abstract}
Within the vocabulary of Old Turkic, there are uncertainty about the etymological analysis of the words ıçıı- and örgin in both inscriptions and manuscripts, as well as in Old Uyghur and Karakhanid Turkic texts. The suffix $\{-n-\}$ at the end of the word $ı$ ģın- and $\{-n\}$ at the end of the word örgin are detectable. Apart from this determination, there is a gap in Turcology regarding the root forms of these two words with verbs connecting root forms to $\{-n-\} /\{-n\}$ suffixes also the second suffix that both words are understood to have. This second suffix seen in the structure of both words seems to be $\{$-gI- $\}$ suffix. The suffix $\{-\mathrm{gI}-\}$ has an important place in the etymological explanation of the words ıçgın- and örgin. The existence of this suffix, which is not included in the etymology dictionaries prepared on vocabulary and word deriving of Old Turkic, seems inevitable when the words Içıı- and örgin are examined in depth. Because the verb örgi- in the south tenth line of the Şine Usu inscription, which is witnessed in the explanation of the word örgin, has a key role in understanding this situation. In this study, firstly, the meanings of the words ıçgin-and örgin will be emphasized with sample testimonies from the vocabulary of Old Turkic. Then, the etymology suggestions for the relevant words will be addressed from a critical point of view. After that the root forms that are thought to be the source of these two words and the
\end{abstract}

Dr., İnönü Üniversitesi, Türk Dili ve Edebiyatı ABD, (Malatya,Türkiye). karamana00@gmail.com. ORCID ID: 0000-0002-25248972. [Araștırma makalesi, Makale kayıt tarihi: 28.06.07.2021-kabul tarihi: 20.08.2021; DOI: 10.29000/rumelide.981496]

Adres $\mid$ Address

RumeliDE Dil ve Edebiyat Araştırmaları Dergisi Osmanağa Mahallesi, Mürver Çiçeği Sokak, No:14/8 Kadıköy - ISTANBUL / TÜRKIYE 34714 e-posta: editor@rumelide.com

RumeliDE Journal of Language and Literature Studies Osmanağa Mahallesi, Mürver Çiçeği Sokak, No:14/8

Kadıköy - ISTANBUL / TURKEY 34714 tel: +90 $5057958124,+902167730616$

e-mail: editor@rumelide.com

phone: +90 5057958124 , +90 2167730616 
suffixs that the words take will be try to explained. In the last part of the article, structural and semantic appearance of the suffix $\{$-gI- $\}$, which was not found in the determinations of researchers such as Clauson, Gabain, Erdal, Orkun and Tekin, will be emphasized in the light of the results obtained.

Keywords: ıçgın-, örgin, \{-gI-\} suffix, etymology, Old Turkic

\section{Giriş}

Eski Türk yazısı (runik / runiform) taşlara işlenmenin yanında kâğıtlar üzerine de yazılmıştır. Runik yazıyla gerek taşlar üzerine işlenmiş gerekse de kâğıtlar üzerine yazılmış kimi belgeler günümüze dek ulaşmıştır. Adı geçen bu yazıtlar ve el yazması eserler, Eski Türkçenin dil özelliklerinin görüldüğü ilk evreyi oluşturmaktadır. Eski Türkçenin özelliklerinin yansıdığı diğer bir evre, başta Budizm olmak üzere Maniheizm, İslâmiyet ve Hristiyanlık gibi inanç sistemlerinin etkisiyle yazılmıș dinî eserler ile herhangi bir inanışın yansımadığı din dışı sivil metinlerden oluşan Eski Uygur Türkçesi evresidir. Eski Türkçe döneminin son evresi ise ilk Türkolog Kâşgarlı Mahmud'un eșsiz eseri DLT'den başka özellikle yeni kabul edilen İslâm dininin yoğun etkisiyle kaleme alınmıș dinî nitelikteki metinlerden oluşan Karahanlı Türkçesi evresidir.

Eski Türkçe konulu çalışmalarda, izi sürülen, takip edilen, araştırılan yapıların anlamsal ve yapısal boyutlarının tam anlamıyla açıklığa kavuşturulabilmesi adına, Eski Türkçe dönemini oluşturan bu üç evrenin tamamı göz önünde bulundurularak değerlendirmelerin yapılması gerekmektedir. Eski Türkçeyi oluşturan bu üç evrenin üçünde de tanıklanan ıçgın- sözcüğü hem anlam hem de yapı bakımından dikkat çekmektedir. Özellikle sözcüğün yapısında bulunan ekler üzerine çeșitli fikirler öne sürülmüș ancak sözcüğün etimolojisi adına açık bir açıklama getirilememiştir. Eski Türk Yazıt ve El Yazmaları evresi ile Eski Uygur Türkçesinde geçmesine karşın Karahanlı Türkçesi metinlerinde tanıklanmayan örgin sözcügü üzerine de benzer biçimde tartışmalar bulunmaktadır. Birbirinden farklı köklere dayanan ve yapılarındaki son eklerin birbirinden farklı olduğu bu iki sözcüğü, aynı yazıda ele aldıran nokta, her iki sözcüğün de almış olduğu anlaşılan \{-gI-\} ekidir. Şimdiye dek sunulan Eski Türkçenin söz yapımında kullanılan ekler listelerinde yer almayan bu ek, ıçgın- ve örgin sözcüklerinin etimolojisinin tatmin edici biçimde yapılabilmesi açısından önemli bir yere sahiptir.

Yapılan bu çalışmada adı geçen bu iki sözcük, ayrı başlıklar altında incelenecektir. Yazıda öncelikle Eski Türkçenin söz varlığındaki tanıklamalarından örnek kullanımlarla ıçgın- ve örgin sözcükleri, anlamsal açıdan ele alınacaktır. Sonrasında, bu iki sözcüğün etimolojisi adına yorum getirmiş kimi Türkolog görüşlerine yer verilecektir. Etimoloji önerilerinden sonra sözcüklerin yapısal çözümlemeleri için yeni bir öneri sunulacaktır. Yazının üçüncü ve son bölümünde ise elde edilen veriler ışığında ıçgın- ve örgin sözcüklerinin yapısında yer alan \{-gI-\} ekinin anlamsal ve yapısal görünümü üzerine kimi düşünceler ortaya konacaktır.

\section{1. lçgın- sözcüğü}

Içgın- sözcüğü, eski Türk yazıtlarında KT D6-13, BK D7-11, o D1 ve O D2'de; el yazmalarında ise yalnızca IB 22 'de 'düşürmek, elinden gitmek, kaybetmek, yitirmek' karşılığıyla geçmektedir. Sözcük, Eski Uygur Türkçesi metinlerinde 'dağılmak, kaybolmak, ufalmak'; Karahanlı Türkçesinde ise 'elinden kaçırmak, kaybedilmek, yok edilmek, elden gitmek, yakalanmak' karşılığıyla tanıklanmıștır (Caferoğlu, 2015: 84; Ünlü, 2012: 301). Sözcügün Eski Türkçenin söz varlığındaki tanıklamalarına bakıldığında mecazî anlamlar kazandığını da belirtmek gerekir. Sözcüğün kullanımlarıyla ilgili kimi örnek tanıklamalar aşağıda verilmiştir:

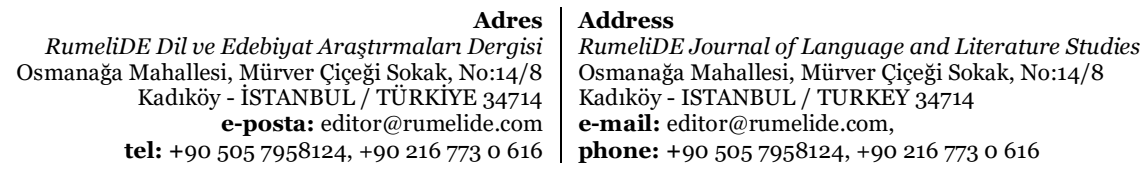

Adres
RumeliDE Dil ve Edebiyat Araştırmaları Dergisi Kalks, Mürver Çiçegi Sokak, No.14/8 tel: +90 505 7958124, +902167730616 
[...] türük bodun élledök élin ıçgınu ıdmış kaganladok kaganın yitürü ıdmış [...] "Türk halkı, yurt tuttuğu toprakları yitirmiş, kağan yaptığı kağanını kaybetmiş̧.” KT D6, BK D7, (Aydın, 2017: 53, 82)

[...] türük törösin ıçgınmış bodunug eçüm apam törösinçe yaratmış boşgurmış [...] “Türk yasalarını kaybetmiş halkı, atalarım dedelerim yasalarına göre (uygun olarak) yeniden örgütlemiş, eğitmiş (öğretmiş)." KT D13, BK D11, (Aydın, 2017: 55, 83)

[...] ol kan yok boltokda késre él yitmişı ıçınmış [...] “O han öldükten sonra yurdu yitirmiş kaybetmişler.” O D2, (Aydin, 2017: 123)

kaganladok kaganın ıçgını ıdmış [...] “kağan yaptığı kağanını kaybedivermiş.” O D2, (Aydın, 2017: 123)

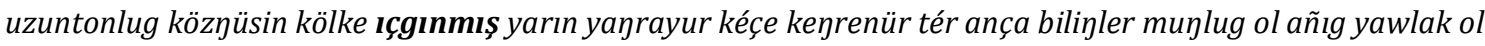
"Bir kadın, aynasını göle düşürmüş (gölde kaybetmiş). (Bu yüzden) Sabah söyleniyor, akşam sızlanıyor. Öylece biliniz ki (bu fal) sıkıntı vericidir, çok kötüdür." (Yıldırım, 2017: 39; Tekin, 2019: 21)

[...] éli kanı él ornın ıçgıngay [...] 434 (VI. 16b.), 8-9. (Kaya, 1994: 328)

[...] öglerin köyüllerin ıçgınıp ne kılınmışın arıtı bilinmez boltılar [...] 625 (X. 14a.), 16. (Kaya, 1994: 328)

[...] öyre suidi kan élin ıçgınıp yértinçü yér suv yémrilti yérilti [...] HT VII, 813. (Röhrborn, 1991: 78)

[...] öz tüzlerin titmedin [ıçg]ınmadın [egsük]ler e[rs]er ? [...] BTT XXVI, 30-31, (Kasai, 2008: 170)

[...] ög ig emgekimin serü umadın birer birer ögümin köjülümin ıçgınur men [...] DKPAM 2694. (Elmalı, 2016: 156)

[...] ol kuşnı eligdin ıçgındı [...] DLT, (Ercilasun ve Akkoyunlu, 2015: 115)

[...] yakadakı yalgagalı eligdeki ıçgınur [...] DLT, (Ercilasun ve Akkoyunlu, 2015: 115)

[...] er ıçgındı [...] DLT, (Ercilasun ve Akkoyunlu, 2015: 115)

[...] süsin keḍ küdezse til ıçġınmasa süsi az üküşin yag்ı bilmese [...] KB, 2350. (Arat, 1979, 249)

Clauson, sözcük için 'to allow (someone or something Acc.), to disappear; to let (something) slip' açıklamasını yapar. Clauson ayrıca sözcüğün dönüşlülük anlatımına sahip olduğunu ancak kökünün bilinmediğini ifade eder (ED 23a-b). Gabain, ıçgın- / ıçgun- biçiminde verdiği sözcüğün 'kaybolmak, kurtulmak' anlamında olduğunu belirtmek dışında herhangi bir yorumda bulunmaz (1988: 273). Tekin, 'ünlülü eylem zarfı $+\imath d$ - 'göndermek' yapısının örnekleri arasında ıçgın- $u$ ıd- 'elden çıkarıvermek' ifadesine yer verir ve ıçgın- sözcüğünün karşıllğı için 'elden kaçırmak, yitirmek' anlamını belirler. Tekin de sözcük üzerine bundan başka bir açıklamaya yer vermez (2003: 99, 244). Şirin User, ıçgın- fiili için '1. çıkarmak, düşürmek, ayırmak, koparmak, sökmek. 2. (il, törü veya kaganı) yitirmek, elden kaçırmak' anlamlarını belirler (2009: 341, 364). Orkun, ıçgın- için 'kaybolmak, bozulmak'; ıçgınu ıd-için ise 'kaçıp gitmek, bozulmak' karşılığını düşünür (2011: 807).

Erdal aşgın- maddesinde, Ercilasun'un \{-gXn-\} ekiyle ilgili görüşlerine yer verir ve Ercilasun'un ıçgın- fiilini bu ekin örnekleri arasında sıraladığını aktarır (1991: 589-590). Erdal ıçgın- maddesinde ise sözcük için 'to lose something, let it go, let it slip away' karşılığını verir ve sözcüğün kök biçimi ile yapısının bilinmediğini

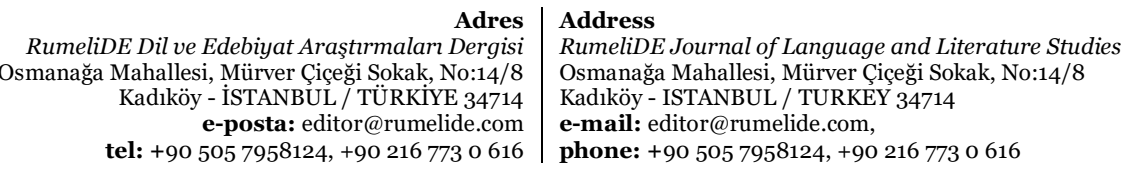


ifade eder (1991: 601). Demirel, Ercilasun'un görüşlerini de atıfladığı yazısında, ıçgın- sözcüğündeki ekin \{gXn-\} eki olduğunu belirtir. Demirel ilgili yazısında, Banguoğlu'nun \{-gXn-\} eki için 'berkitme fiilleri yapan ek -ik- üzerine -in- dönüşlü çatı ekinin getirilmesiyle ortaya çıkmış olabileceği' düşüncesini aktarır. Yine Demirel, Tietze'nin söz konusu ek için 'orta dönüşken -1k- eki ve dönüşlülük eki -(1)n- ekinin birleşmesiyle oluştuğu' görüşünü ifade eder (2017: 2127-2128).

Içıın- fiilinde Clauson ve Demirel'in ifade ettiği dönüşlülük anlatımı, sözcüğün sonunda yer alan ve Eski Türkçenin söz yapımında sık biçimde tanıklanan $\{-n-\}$ ekinden kaynaklanmaktadır. Sözcüğün yazıtlardaki kullanımlarına bakıldı̆̆ında açık biçimde 'yurt topraklarını, yasalarını ve kağanını' kaybeden halktır ve bu durumdan etkilenen de yine halkın kendisidir. IB 22'de geçen cümlelerin öznesi uzuntonlug'tur. Aynasını göle düşüren de bu durumdan kaynaklı olarak sızlanıp söylenen de yine kadının kendisidir. Bu itibarla sözcüğün yapısındaki son ekin $\{-n-\}$ eki olduğu açıktır. Eski Türkçenin söz varlığında şimdiye dek yalnızca KB 1532'de tanıklanan bir ıç-fiili vardır:

\section{[...] ara bir ıçar kör yorır belgüsüz ara köz körürde bolur belgüsüz [...] (Arat, 1979: 170)²}

Ünlü, ıç- fiili için 'kaybolmak, saklanmak, gizlenmek' karşllğını verir (2012: 301). Satırın bağlamından, buradaki ıç- fiili için belirlenecek en uygun anlamın 'kaybolmak' olduğu anlaşılmaktadır. Satırın başındaki ara bir ıçar ifadesi 'kimi zaman kaybolur' biçiminde karş̧lanabilir. Bu noktada, ıçgın- sözcüğünün karşıladığı anlamlar ile ıç- fiilinin 'kaybolmak' anlamı arasındaki ilişki yadsınamaz durumdadır. Böylece ıçgınsözcügünün kök biçimi için ıç- fiili zorlamaya yer olmadan tespit edilebilir. Iç- fiili ile ıçgın- sözcügü arasındaki anlamsal bağlantı anlaşıldıktan sonra ıç- fiilinin nasıl $\{-n-\}$ ekine bağlanabileceği üzerinde durulabilir. Banguoğlu ve Tietze'nin \{-gXn-\} eki için düşündükleri \{-1k- / -ik- + -ln-\} tespiti, ıçgın-fiilinin ses ve hece yapısına uygun değildir. Eski Türk yazısında (runik / runiform) lk/kı sesi için ayrı bir işaret vardır. Ancak ıçgın- sözcüğü açık biçimde $I \zeta g^{1} n^{1}$ biçiminde yazılmıştır. Burada sözcüğün kök biçiminin $ı c ̧$ - fiili olduğu ile sözcüğge getirilen son ekin \{-n-\} eki olduğu belirlendikten sonra sözcüğün aldığı ilk ekin ne olduğu, yazının üçüncü bölümünde açıklanmaya çalışllacaktır.

\section{2. örgin sözcüğü}

Örgin sözcügü̈, eski Türk yazıtlarında Tes G2, Ta G6, Ta B1-2, ŞU D8-9, ȘU B6, ȘU G10, KarB I, II/8'de; el yazmalarında ise yalnızca IB 1'de 'kağanlık otağı, taht' karşılığıyla tanıklanmıştır. Sözcük, Eski Uygur Türkçesinde örgin / örgün biçiminde 'taht' karşllığıyla tanıklanırken Karahanlı Türkçesi metinlerinde geçmemektedir (Caferoğlu, 2015: 152). Sözcüğün kullanımlarıyla ilgili kimi örnek tanıklamalar aşağıda verilmiştir:

[...] kasar kur $<\imath>g$ kontı çıt tikdi örgin yaratdı yayladı "Kasar'ın batısına yerleşti. Çit dikti, tahtını kurdurdu. Yazı (orada) geçirdi.” Tes G2, (Aydın, 2018: 37)

[...] ötüken ortosınta as öyüz baş kan ıdok baş kédinin örgin bunta éti<t>dim “Ötüken'in ortasında As Öngüz Baş (ve) Kan Iduk Baş (dağlarının) batısında kağanlık otağını burada kurdurdum.” Ta G6, (Aydın, 2018: 44)

[...] <...> kagan atıg katun atıg atanıp ötüken kédin uçınta tez başınta örgin [anta étitdim çıt] anta yaratıtdım [...] “<...> kağan adını hatun adını alıp Ötüken'in batı ucunda, Tes (Irmağı'nın) kaynağında kağanlık otağını orada kurdurdum, karargâh çitlerini orada vurdurdum." Ta B1, (Aydın, 2018: 44)

\footnotetext{
2 Tezcan, ilgili beyitteki ifadenin yir içer biçiminde okunmasının daha doğru olacağı kanısındadır (1981: 40-41). Adres | Address

RumeliDE Dil ve Edebiyat Araşturmalar Dergisi $\quad$ RumeliDE Journal of Language and Literature Studies Osmanağa Mahallesi, Mürver Çiçeği Sokak, No:14/8 $\quad$ Osmanağa Mahallesi, Mürver Çiçeği Sokak, No:14/8 Kadıköy - ISTANBUL / TURKIYE 34714 Kadıköy - ISTANBUL / TURKEY 34714 e-posta: editor@rumelide.com e-mail: editor@rumelide.com, tel: +90 505 7958124, +90 2167730616 phone: +90 505 7958124, +90 2167730616
} 
[...] ötüken ortosınta as önüz baş kan ıdok baş kédininte yayladım örgin bunta yaratı<t>dım çıt bunta tokıtdım [...] “Ötüken'in ortasında As Öngüz baş (ile) Kan Iduk Baş (dağlarının) batısında yayladım. Kağanlık otağını burada yaptırttım. Karargâh çitlerini burada vurdurdum." Ta B2, (Aydın, 2018: 44)

[...] anta yana tüşüp orkon ballkllg beltirinte él örginin anta örgipen étitdim [...] "Oradan yine geri dönüp Orhon Irmağı (ile) Balıklıg Irmağı'nın birleştiği yerde ülkenin tahtını (yönetim merkezini) orada yükselttirip düzenlettim." ŞU G10, (Aydın, 2018: 61-62)

tensi men yarın kéçe altun örgin üze olurupan meyileyür men ança bilinler edgü ol "Ben Tensi'yim! Sabah akşam altın taht üzerinde oturup mutlu bir biçimde yaşarım. Öylece biliniz ki (bu fal) iyidir." (Yıldırım, 2017: 33; Tekin, 2019: 19)

[...] sögütler altınınta vaydurı erdini üzeki örgünler üzesinte olurup [...] 93 (II. 30a.), 1. (Kaya, 1994: 103)

[...] erdinilig lınhualıg örgünler üze olorup [...] 380 (V. 18b.), 21. (Kaya, 1994: 224)

[...] kim ol örginniy özinteg ortosinteg oroninteg olorgusinteg bolup tururlar [...] BTT V, 175. TI D20 (U 262), 7. (Zieme, 1975: 31)

[...] otra[sınta vaji]rlıg vaçrazan [örgün ol] [...] HT III, 335. (Ölmez ve Röhrborn, 2001: 67)

[...] sogançıg kutlug vaçrazan örgündeki mahabodiram senremde erigme üküş̧ bilgeler kuvragı üze kavzatılmış [...] HT VII, 1840-1841. (Röhrborn, 1991: 158)

[...] ögre bodi sögüt tüpinte vaçrazan örgün üze oluru yarllkadokta [...] HT VIII, 883-884. (Röhrborn, 1996: 85)

[...] azu yme édiz örgün üze agtınıp ulug teriy kuvragka nom nomlayur bol[ur] [...] HT X, 172. (Mirsultan, 2010: 88)

[...] toyın dintar bolayın ötrü otgurak katag köjülin örgüninte kodı éne inçe tép sav sözleyür [...] 47, 22. (Tekin, 2019: 101)

Örgin sözcüğünün kaynağını Moğolca'da tespit ettiğini düşünen Ramstedt, sözcüğü örgüge ve *örgü- ile karşllaştırır (1913: 53). Clauson, örgin 'throne' sözcügünün örge- fiilinden geldiğini düşünür. Ona göre örgefiili de örüg adından gelmektedir (ED 225b, 226a-b). Clark, sözcügün Moğolca olduğunu belirtir ve ör- 'to rise' fiilne \{-gIn\} ekinin getirilmesiyle kurulduğunu düşünür (1977: 142). Tekin, 'hakan otağı, saray, konak, taht' biçiminde anlamlandırdığı sözcüğün örgi- 'yükseltmek, kurmak; hakan çadırı ve tahtı kurmak' fiiline \{(X)n\} ekinin getirilmesiyle oluştuğu görüşündedir (2003: 92, 251). Şirin User, sözcüğü 'kağan otağı' biçiminde anlamlandırır (2009: 242). Ölmez, sözcüğün yapısının iki biçimde açıklanabileceğini belirtir: *ör(ü)g+e- (< ör- 'yükselmek, örerek yükselmek') veya *örgi- < örg+i- (2018: 163). Aydın ise sözcüğün örgi'yükseltmek' fiilinden yapıldığını düşünür. Ona göre sözcük, Türkçeden Moğolcaya verilmiş bir ödünç sözcük olabilir (2018: 162). ${ }^{3}$

Örgin sözcüğünün sonundaki ekin $\{-\mathrm{n}\}$ eki olduğu, ŞU G10'da tanıklanan örgi- fiilinin varlığından anlaşılmaktadır. 'Otağ, taht kurmak, yükseltmek, kurmak' karşllı̆ındaki bu örgi- fiilinin de bir kök biçim olmadığı söylenebilir. Eski Türkçenin söz varlığında tanıklanan bir ör-kök biçimi vardır. Bu kök biçim, Eski

Daha geniş bilgi için ayrıca bk. Aydın, 2018: 162 .

RumeliDE Dil ve Edebiyat Araştırmaları Dergisi Osmanağa Mahallesi, Mürver Çiçeği Sokak, No:14/8 Kadıköy - İSTANBUL / TÜRKIYE 34714 e-posta: editor@rumelide.com tel: +90 $5057958124,+902167730616$

Address

RumeliDE Journal of Language and Literature Studies

Osmanağa Mahallesi, Mürver Çiçeği Sokak, No:14/8

Kadıköy - ISTANBUL / TURKEY 34714

e-mail: editor@rumelide.com,

phone: +90 5057958124 , +90 2167730616 
Uygur Türkçesi metinlerinde 'yükselmek, çıkmak'; Karahanlı Türkçesinde ise 'örmek, bağlanmak; belirmek, çıkmak, kopmak, yükselmek; ayağa kalkmak' anlamlarını karşılamaktadır (Caferoğlu, 2015: 152; Ünlü, 2012: 614-615). Örgi- fiili ile ör- fiili arasındaki anlamsal bağlantı anlaşılır durumdadır. Çünkü 'kağanlık otağı, taht' yerden yukarıya 'yükseltilmiş' bir yapıya sahiptir. Ör- filil eski Türk yazıtlarında iki yerde tanıklanmıştır. Sözcügün Teke-Turu yazıtının 1. satırındaki kullanımı, ör- fiili ile örgi- fiili arasındaki anlamsal ilgiyi kanıtlar niteliktedir:

ew örti // ew örtti "Ev yükseldi (çadır kuruldu) // ev inşa etti." (Tıbıkova vd. 2012: 126-127; http://www.altay.uni-frankfurt.de/A53/A53_0.HTM)

Sözcüğün yazıtlardaki diğer kullanımı ise KT B'dedir. Ör- fiili burada 'ayaklanmak, isyan etmek' anlamını karşılamaktadır. Bu anlam, sözcüğün 'ayağa kalkmak' karşılığıyla ilgilidir. Ör kök biçiminin bir sesteş kök olduğunu da belirtmek gerekir. Ör adının Maytrısimit'de 'taht' anlamıyla geçmesi ilgi çekicidir (Tekin, 2019: 446). Ör adı DLT'de ise 'kaftanın koltuk altı' karşılığıyla tanıklanmıştır (Ercilasun ve Akkoyunlu, 2015: 21). Örgin sözcügünü yapısal açıdan açıklamak için \{-gIn\} ekinin kullanılması kabul edilebilir durumda değildir. Çünkü örgi- fiili tek başına tanıklanmıştır. Sözcüğün Moğolca kökenli olduğu görüşlerine karşın özellikle ör fiilinin Türkçenin söz yapımı ve anlam dünyası açısından zorlayıcı açıklamalara gerek bırakmayacak biçimde örgi- ve örgin sözcüklerine geliştiği söylenebilir. Burada örgin sözcüğünün kök biçiminin ör- fiili olduğu ile sözcüğe getirilen son ekin $\{-n\}$ eki olduğu belirlendikten sonra sözcüğün aldığı ilk ekin ne olduğu, yazının üçüncü bölümünde açıklanmaya çalışılacaktır.

\section{3. \{-gI-\} Ekinin yapısal ve anlamsal görünümü üzerine düşünceler}

'Yükselmek' karşllğındaki ör- fiilini 'yükseltilmiş' bir niteliğe sahip olan 'kağan otağı; taht' sözcüğüne bağlayan fiil, 'otağ, taht kurmak, yükseltmek, kurmak' karşılı̆̆ındaki örgi- fiilidir. Örgi- fiili burada 'otağı, tahtı yükseltme' işine işaret etmektedir. Bu itibarla ör-fiilini örgin sözcüğüne bağlayan ekin fiillere gelerek yeni fiiller türeten \{-gI-\} eki olduğu sorunsuzca tespit edilebilmektedir. Burada farklı yorumlara yer bırakmayan iki noktadan biri örgi- fiili diğeri ise $\{-n\}$ ekinin yadsınamaz varlığıdır. \{-gI- $\}$ ekinin eklendiği fiili, 'otağın, tahtın yükseltilmesi, kurulması' işi göz önünde bulundurularak kesin olmamakla birlikte yeryön bakımından etkilediği düşünülebilir. Çünkü sözü edilen üretim, 'aşă̆ıdan yukarıya' doğru yapılan bir eylemin sonucunda ortaya çımaktadır.

Iç- 'kaybolmak' fiilinden türediği anlaşılan ıçgın- sözcüğünün barındırdığı dönüşlülük anlatımını sağlayan ekin \{-n-\} eki olduğu anlaşılmaktadır. Bu durumda elde, bir ıç- kökü bir de dönüşlülük bildiren $\{-n-\}$ eki vardır. Bu itibarla gerek ses ve yapı gerekse de anlam ve bildirişim açısından, ıç- kök biçimini ıçgın- fiiline bağlayan ekin \{-gI-\} eki olduğu sonucu zorlamaksızın ortaya çıkmaktadır. Burada oluşan * ${ }^{*}$ ģgı- fiili henüz tek başına Eski Türkçenin söz varlığında tanıklanamamıștır. ${ }^{*}$ Içgl- fiilinin karşıladığı anlamın hem ör-< örgigelişimine hem de ıçgın- fiilinin 'düşürmek, elinden gitmek, yitirmek' karşılı̆̆ına bakılarak 'kaybetmek' biçiminde olduğu söylenebilir. Ör- 'yükselmek' < örgi- 'yükseltmek; ıç- 'kaybolmak' < *ıçgı- 'kaybetmek'. İlginç biçimde, tıpkı ör- fiilinin örgin adına geliştiği noktada 'aşağıdan yukarıya' doğru yapılan bir işten söz edildiği gibi ıç- kök biçiminin ıçgın- fiiline geliştiği noktada da mantıksal açıdan 'yukarıdan aşağıya' oluşan bir durumdan söz edilebilir. Bu noktada, ıçgın- fiilinin 'düşürmek, elden gitmek' temel anlamından 'yitirmek, dağılmak, ufalmak' anlamına doğru geliştiği anlaşılmaktadır. Kölke ıçgınmış ifadesi, bu durumun anlaşılması için güzel bir örnektir. Yine kesin olmamakla birlikte \{-gI-\} ekinin ıçgın-filini yer-yön bakımından etkilediği düşünülebilir. Böylece eldeki veriler ışığında, \{-gI-\} ekinin fiillere gelerek yeni fiiller türeten ve eklendiği fiilleri yer-yön bakımından etkileyen nitelikte bir ek olduğu söylenebilir.

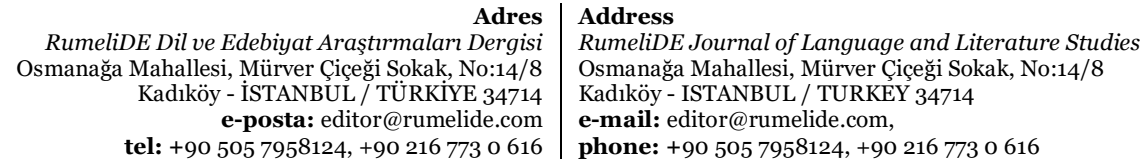

Adres
RumeliDE Dil ve Edebiyat Araştırmaları Dergisi tel: +90 $5057958124,+902167730616$ 


\section{Sonuç}

1. 'Düşürmek, elinden gitmek, kaybetmek, yitirmek, dağılmak, ufalmak, kaçırmak, kaybedilmek, yok edilmek, yakalanmak' karşılığındaki ıçgın- sözcüğünün ıç- 'kaybolmak' kök biçimine sırasıyla \{-gI-\} ve \{-n-\} ekinin getirilmesiyle kurulduğu anlaşılmaktadır.

2. 'Kağanlık otağı, taht' karşılığındaki örgin sözcüğünün ör- 'yükselmek' kök biçimine sırasıyla \{-gI- $\}$ ve $\{-n\}$ ekinin getirilmesiyle oluştuğu görülmektedir.

3. Etimoloji sözlüklerinde işaret edilmeyen $\{$-gl- $\}$ eki, Eski Türkçenin söz yapımında kullanılan ekler listesindeki yerini almalıdır.

4. Yapılan inceleme sonucunda, eldeki verilere bakılarak $\{$-gI- $\}$ ekinin fiillere gelerek yeni fiiller türeten ve eklendiği fiilleri yer-yön bakımından etkileyen nitelikte bir ek olduğu söylenebilir.

\section{Kisaltmalar}

$\mathrm{AY} \rightarrow$ Altun Yaruk.

$\mathrm{BK} \rightarrow$ Bilge Kağan Yazıtı.

BTT $\rightarrow$ Berliner Turfantexte.

DKPAM $\rightarrow$ Daśakarmapathāvadānamālā.

DLT $\rightarrow$ Dīvānu Lugāti't-Türk.

ED $\rightarrow$ Clauson 1972.

$\mathrm{HT} \rightarrow$ Xuanzang Biyografisi.

IB $\rightarrow$ Irk Bitig.

$\mathrm{KB} \rightarrow$ Kutadgu Bilig.

KT $\rightarrow$ Köl Tegin Yazıtı.

$\mathrm{O} \rightarrow$ Ongi Yazıtı.

ŞU $\rightarrow$ Şine Usu Yazitı.

$\mathrm{Ta} \rightarrow$ Tariat (Terh) Yazıtı.

\section{Kaynakça}

Arat, R. R. (1979). Kutadgu Bilig I metin. Ankara: TDK.

Aydın, E. (2017). Orhon yazıtları Köl Tegin, Bilge Kağan, Tonyukuk, Ongi, Küli Çor. İstanbul: Bilge Kültür Sanat.

Aydın, E. (2018). Uygur yazıtları. İstanbul: Bilge Kültür Sanat.

Caferoğlu, A. (2015). Eski Uygur Türkçesi sözlüğü. Ankara: TDK.

Clauson, S. G. (1972). An etymological dictionary of pre-thirteenth-century Turkish. Oxford: Oxford University.

Clark, L. V. (1977). “Mongol elements in old Turkic?”. JSFOu. 75, 110-168.

Demirel, E. (2017). “Kuçgundı ‘soğan’ sözcüğünün kökeni üzerine”. Teke Dergisi, 6/4, 2122-2131.

Elmalı, M. (2016). Daśakarmapathāvadānamālā giriş - metin - çeviri - notlar - dizin - tıpkıbaskı. Ankara: TDK.

Ercilasun, A. B. ve Akkoyunlu, Z. (2015). Kâşgarlı Mahmud Dîvânu Lugâti't-Türk giriş - metin - çeviri - notlar - dizin. Ankara: TDK.

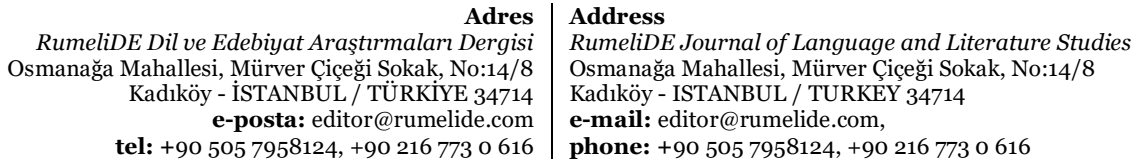


Erdal, M. (1991). Old Turkic word formation: A functional approach to the lexicon, I-II. Wiesbaden: Otto Harrassowitz.

Gabain, A. Von. (1988). Eski Türkçenin grameri (çev. Mehmet Akalın). Ankara: TDK.

http://www.altay.uni-frankfurt.de

Kasai, Y. (2008). Die Uigurischen buddhistischen kolophone (Berliner Turfantexte XXVI). Turnhout: Brepols.

Kaya, C. (1994). Uygurca Altun Yaruk, giriș, metin ve dizin. Ankara: TDK.

Mirsultan, A. (2010). Veröffentlichungen der societas Uralo Altaica band 34, Xuanzang leben und werk teil 9 , Die alttürkische Xuanzang-biographie X. Wiesbaden: Harrassowitz.

Orkun, H. N. (2011). Eski Türk yazıtları. Ankara: TDK.

Ölmez, M. ve Röhrborn, K. M. (2001). Veröffentlichungen der societas Uralo Altaica band 34, Xuanzang leben und werk teil 7, die alttürkische Xuanzang-biographie III. Wiesbaden: Harrassowitz.

Ramstedt, G. J. (1912). "Prevod nadpisi selenginskogo kamnya”. Trudı Troitsko-Kyahtinskogo Otdeleniya Imperatorskogo Russkogo Geografiçeskogo Obşestva, 15/1, 40-49.

Röhrborn, K. M. (1991). Veröffentlichungen der societas Uralo Altaica band 34, Xuanzang leben und werk teil 3, die alttürkische Xuanzang-biographie VII. Wiesbaden: Harrassowitz.

Röhrborn, K. M. (1996). Veröffentlichungen der societas Uralo Altaica band 34, Xuanzang leben und werk teil 5, die alttürkische Xuanzang-biographie VIII. Wiesbaden: Harrassowitz.

Şirin User, H. (2009). Köktürk Ötüken Uygur Kağanlığı yazıtları söz varlığı incelemesi. Konya: Kömen.

Tekin, T. (2003). Orhon Türkçesi grameri. İstanbul: TDAD.

Tekin, T. (2019). Irk Bitig eski Uygurca fal kitabı, Ankara: TDK.

Tekin, Ş. (2019). Uygurca metinler II, Maytrısimit, burkancıların mehdisi Maitreya ile buluşma Uygurca iptidai bir dram. Ankara: TDK.

Tezcan, S. (1981). “Kutadgu Bilig dizini üzerine”. Türk Dili Araştırmaları Yıllığı - Belleten, XLV/2, (178), 23 78.

Tıbıkova, L. vd. (2012). Katalog drevnetyurkskih runiçeskix pamyatnikov gornogo Altaya. Gorno-Altaysk: Gorno-Altaysk Gosudarstvenniy Universitet.

Ünlü, S. (2012). Karahanlı Türkçesi sözlüğü. Konya: Eğitim.

Yıldırım, F. (2017). Irk Bitig ve Orhon yazılı metinlerin dili. Ankara: TDK.

Zieme, P. (1975). Manichäisch-Türkische texte, übersetzung, anmarkungen, (Berliner Turfantexte V). Berlin: Akademie.

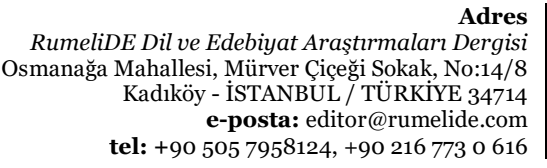

Adres
RumeliDE Dil ve Edebiyat Araştırmaları Dergisi Kadiköy - IS tel: +90 $5057958124,+902167730616$
Address

RumeliDE Journal of Language and Literature Studies Osmanağa Mahallesi, Mürver Çiçeği Sokak, No:14/8

Kadıköy - ISTANBUL / TURKEY 34714

e-mail: editor@rumelide.com,

phone: +90 5057958124 , +90 2167730616 